\title{
Underpricing in a Capital Market: Case of Latvia
}

\author{
IRINA SOLOVJOVA \\ Department of Finance and Accounting \\ University of Latvia \\ 5 Aspazijas blvd, Riga, LV-1050 \\ LATVIA \\ KONSTANTINS TALIKOVS \\ Electronics and Telecommunications faculty \\ Riga Technical University \\ 12 Azenes str., Riga, LV-1048 \\ LATVIA \\ LYDIA GOLUBEVA \\ Department of Finance and Accounting \\ University of Latvia \\ 5 Aspazijas blvd, Riga, LV-1050 \\ LATVIA \\ ANNA LITVINENKO \\ Electronics and Telecommunications faculty \\ Riga Technical University \\ 12 Azenes str., Riga, LV-1048 \\ LATVIA \\ RUTA SVĒTIN,A \\ Centre for Applied Linguistics \\ University of Latvia \\ 5 Aspazijas blvd, Riga, LV-1050 \\ LATVIA
}

\begin{abstract}
The study is devoted to a little studied IPO underpricing problem. IPO underpricing is the difference between the IPO offer price paid by institutional and individual investors who commit to buying shares before trading on the Stock Exchange and the closing price, which is the last trading price recorded when the market closes at the end of the day. This price difference shows the extent to which the company did not value itself and how much capital it did not make due to the too low offer price. By assessing the price difference and multiplying it by the number of shares issued in public turnover on the Stock Exchange, the company can calculate exactly how much capital it could additionally invest in financing growth and business development, which in the long term would also create added value to the entire national economy. The aim of the study is to research the problem of underpricing in the Baltic capital market.
\end{abstract}

Key-Words: - underpricing, IPO, offer price, closing price

Received: April 29, 2021. Revised: January 21, 2022. Accepted: February 1, 2022. Published: February 18, 2022.

\section{Introduction}

Stock market financing opportunities in Latvia and the Baltics as a whole are still not being fully realized and used, although interest and demand from potential investors are growing. However, there is insufficient state action to consistently stimulate the development of the securities market, both at political and economic level.

The development of capital and securities markets allows for diversification of the institutional 
structure of lending by increasing the flow of financial capital between investors and issuers of securities and improving the circulation and rate of return of financial capital in the economy as a whole. An active financial market environment opens up a wide range of possibilities for more efficient and dynamic use of savings, which is particularly relevant in the context of low interest rates for different categories of investors. For entrepreneurs, it diversifies the forms and possibilities of attracting external financing.

Problems related to the stock market have been actively researched, but there is an aspect that was not previously given so much attention by researchers - IPO underpricing. The aim of the study is to investigate the problem of underpricing in the Baltic capital market.

The course of the study uses the content analysis method, as well as econometric, statistical analysis and graphical display methods are used.

\section{Problem Formulation}

Financial analysts and scientists around the world have been studying the phenomenon of IPO underpricing for several years. IPO underpricing is the difference between the offer price and the closing price of an IPO offer. The offer price is what institutional and individual investors pay when they commit to buying shares before trading on the Stock Exchange. Closing price is the last trading price recorded when the market closes at the end of the day. If, at the close of the first day of trading, the share price is higher than the offer price, it means that investors were willing to pay more for the shares of the companies, and this difference, multiplied by the number of shares issued, is the unearned capital, which is called "money left on the table" in English.

\subsection{Pricing Models}

Selection of the cooperation partner (financial intermediary) that will provide qualitative assistance in the process of initial placement of shares is very important. A financial intermediary may issue securities for consideration or guarantee the placement of a shares, or underwriting. Companies prevail over the latter option, because the process of issuing shares is complicated and lengthy, to carry it out on their own without experience will require an extremely large consumption of time and strength. Guaranteed placement (underwriting) means that the financial intermediary undertakes not only to place shares on the primary market, but also to provide the issuer with a guarantee of receiving a certain amount of money for the entire issue of the shares [1]. Consequently, the company is less at risk when using the underwriter's service. At the same time, cooperation with intermediaries is an additional cost that must be taken into account when planning the costs of the process. It is considered that, out of all the costs associated with the issue of shares, the investment bank's support and assistance is the most expensive service, which could cost between 3.5\% and $7 \%$ of the capital raised in the IPO [2]. Extensive experience with IPOs is a very valuable advantage of a financial market intermediary among other providers of such services. The better the reputation of the company's consultant for organized public offers in a particular industry, the more likely the company is to successfully implement the IPO. In addition, empirical studies that analyzed the economic role of intermediaries in the IPO process found evidence that financial advisers with better reputation are able to value and sell shares of companies at the highest price [3]. The sale price of the shares, in turn, determines how much capital the company will be able to receive from a realized IPO. In the context of the study, a very important aspect relates to the pricing of which the company plans to sell its shares. The intermediary must assess the enterprise in order to be able to determine the range of the share price (minimum and maximum price) at which it will be offered to investors. The process of setting the share price is complex and very serious. The intermediary should not make mistakes and underestimate the company, because then less capital will be received for the development of the company. Nor should a too high price be set, which in turn will lead to too low demand for shares by investors and an IPO may fail.

There are several approaches in which an intermediary usually assesses a company before setting an offer price, but one of the three methods is most often used: the method of comparing market data, the discounted cash flow method, the method of discounting dividends [4].

The comparable company method is the most understandable and familiar approach to determining the value of a company's shares. According to this method, several financial and performance indicators or multipliers (comparative indicators) of the company are compared with another similar company of the relevant sector on the market, the shares of which are listed on the Stock Exchange. Thus, knowing what price investors are willing to pay for shares of similar companies already active, it is possible to determine the market value of the company being valued. 
Once the comparable companies are selected, calculations can be made using equity and company value multipliers $(\mathrm{P} / \mathrm{E}$ price earnings ratio, $\mathrm{P} / \mathrm{CF}$ price cash flow ratio, $\mathrm{P} / \mathrm{BV}$ price-to-book ratio, $\mathrm{P} / \mathrm{S}$ price to sales ratio, EV/Sales enterprise value-tosales ratio, EV/EBITDA enterprise value to earnings before interest, taxes, depreciation and amortization, etc.).

The discounted cash flow method is a widely used approach based on discounting forecast cash flows at the investor's expected rate of return (discount rate). In practice, this method often has limited use, as it can be difficult to determine future cash flows and an accurate discount rate. The free cash flow used in the discounted cash flow method that the company has at its disposal at the end of the financial year is calculated on the basis of the information presented in the company`s financial statements.

The dividend discounting model determines the value of the company by calculating the present value of the expected future dividends that the company will pay to its shareholders. Most often, investment banks use this model when assessing stable and profitable companies that regularly pay dividends. This is due to the fact that it is relatively difficult to forecast dividends for new companies for which historical data are not available [5].

The results of the researches lead to the conclusion that intermediaries usually choose to apply several approaches to determining the value of the company set at the same time [5]. It should also be taken into account that the market value of the enterprise is determined not only by financial, but also by non- financial indicators, which provide a high added value to the enterprise. Innovations, customer and employee relationships, technologies, brand value, human capital, corporate governance, etc. are defined as non-financial indicators $[6,22]$. Once the intermediary has assessed the company, he discusses the price range of the IPO offer with the company's management, which will later be included in the issue prospectus. However, it should be noted that after meetings with institutional investors, price update is possible.

\subsection{Underpricing Aspects}

A correctly determined price is crucial in the IPO process. But there are many examples where the price was set incorrectly. Zoom began trading the shares on April 18, 2019 on the Nasdaq exchange. The company's share offer price was set at $\$ 36$ per share. A total of 20,869,565 shares were put into circulation. Multiplying the offer price by the number of shares in a public circulation, Zoom has raised \$584.3 million (see Fig. 1).

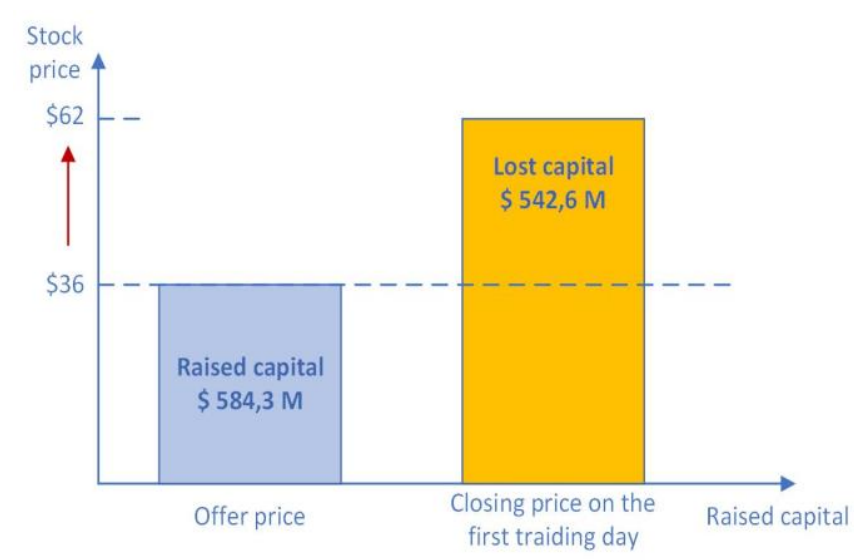

Fig. 1: Initial public offer of "Zoom Video Communications Inc"

On the first day of trading, however, the share price soared and the day ends at a price of 62 dollars per share. This means that the investment bank that helped Zoom launch the stock issue underestimated the company, resulting in it not getting nearly as much as it raised - \$542.6 million, that is multiplication of the closing price by the number of shares. According to mathematical calculations, the total underpricing amounted to $72.2 \%$ [7].

The underpricing aspect attracted a lot of attention in almost all countries of the world, although most often it was studied in the United States (USA), which is the leader in the number of IPOs. Professor Jay R. Ritter from University of Florida has published a number of studies related to the IPO [7], which also focused on underpricing aspects. The professor's blog on the university internet site provides statistical data on the average underpricing rate in 54 countries around the world [8]. The number of IPOs analyzed varies greatly across countries and the largest number of IPOs was researched in the USA, where this number reached 13,490 companies. Average underpricing or average initial return varies considerably from country to country, starting at $3.3 \%$ in Russia, reaching up to $270.1 \%$ in the United Arab Emirates (UAE). Undoubtedly, the results obtained in UAE could be influenced by a small number of companies, which amounted to only 24 companies. Among the countries with a sample of several thousand companies - Australia, China, Hong Kong, India, Japan, Korea, Taiwan, Great Britain and the USA, the distribution of underpricing is also significant, starting with better or lower results in the UK (15.7\%), the USA (17.2\%) and Australia (19.8\%), 
reaching up to $170.2 \%$ in China, which is exactly 10 times more than in the USA.

As mentioned above, the intermediary is responsible for calculating the value of the company and determining the offer price. Thus, the amount of capital that the company will receive depends on the decisions taken by the intermediary. There exist several studies on the phenomenon of underpricing affecting companies which are issuing shares $[9,10$, $11,12,13,14,15]$. It is important to note that theories are based on different aspects of the relationship between investors, issuers and investment banks. In the context of our research, we will consider the theory of IPO underperformance $[16,18,21]$.

As soon as a company with stock trading enters the Stock Exchange, its share price, which reflects the value of the company, should not differ significantly from the share price of similar companies. Otherwise, investors will consider that the shares are overvalued and the investment will not be so profitable. However, at the end of the 20th century, when the scientists began to study empirically the profitability of IPO companies compared to the performance of market indices or similar companies, it was found that IPO companies show lower yields. One of the first theories developed by a professor at New Orleans University, Edward M. Miller, states that investors are willing to pay more for the company's shares than they should because of an overly optimistic mood. However, according to the IPO, investors already have the opportunity to keep the track of the company's progress. Seeing the real value of the company, the optimistic mood of investors will begin to decrease, so the share price will also fall to the average value of the market. According to research by American professor Jay R. Ritter, this happens within three years of the company's IPO. In addition, Jay R. Ritter highlights as one of the IPO phenomena the "hot IPO market", which has already been mentioned at the motivation of companies to conduct IPOs. At a time of market growth, a socalled "a window of opportunity" period is created, when the company's management knows that their shares will be overvalued, thus being able to raise more capital. So, as Edward Miller's theory says, once the enthusiasm of investors drops, the company's stock yields will also fall. Thus, companies that carry out IPOs during the market growth period will perform worse than similar companies (analogous), since the subsequent disclosures about financial indicators will force the market to adjust the fair value of the company [15]. According to Jay R. Ritter's calculations of IPO profitability between 1980 and 2019, after five years IPO companies had $2.4 \%$ lower profitability than the peer companies selected for comparison [16].

\section{Problem Solution}

\subsection{IPO Underpricing in the Baltic States}

The main purpose of the initial public offer is to raise additional capital, it is important for the company to determine the highest price for its shares, at which investors would be happy to buy them. Thus, the management of the company should look at the trends of underpricing on a particular Stock Exchange, especially by sector, in order to understand what is the possible level of underpricing that they should expect.

Within the framework of the research, the level of underpricing is calculated for companies listed on the Baltic Stock Exchange. For calculations, the classic underpricing formula is used:

$$
\begin{aligned}
& \text { Underpricing , } \%=\frac{\text { closing price }- \text { offer price }}{\text { offer price }}- \\
& \frac{\text { oMX last value }- \text { oMX starting value }}{\text { OMX last value }} * 100 \%
\end{aligned}
$$

The difference between the offer price and the closing price is subtracted from the yield of the company's domestic Stock Exchange index on the first day of trading in the stock in order to prevent the impact of market volatility on the underpricing level. Data on 17 companies that joined the Stock Exchange between 2004 and 2020 and are currently listed on the Baltic Stock market were used for the study.

Table 1. Nasdaq Baltic market IPO companies

\begin{tabular}{|c|c|c|c|}
\hline State & $\begin{array}{l}\text { Company } \\
\text { name }\end{array}$ & $\begin{array}{c}\text { Under- } \\
\text { pricing } \\
(\%)\end{array}$ & Industry \\
\hline Estonia & $\begin{array}{l}\text { Saunum } \\
\text { Group }\end{array}$ & 68.86 & $\begin{array}{l}\text { Consumer } \\
\text { products and } \\
\text { services }\end{array}$ \\
\hline Estonia & $\begin{array}{l}\text { Ekspress } \\
\text { Grupp }\end{array}$ & 20.34 & Media \\
\hline Latvia & $\begin{array}{l}\text { MADARA } \\
\text { Cosmetics }\end{array}$ & 15.83 & $\begin{array}{l}\text { Consumer } \\
\text { products and } \\
\text { services }\end{array}$ \\
\hline Estonia & $\begin{array}{l}\text { Tallinna } \\
\text { Vesi }\end{array}$ & 14.62 & Improvement \\
\hline Estonia & $\begin{array}{l}\text { Tallinna } \\
\text { Sadam }\end{array}$ & 13.49 & $\begin{array}{l}\text { Industrial } \\
\text { goods and } \\
\text { services }\end{array}$ \\
\hline Estonia & $\begin{array}{l}\text { EfTEN Real } \\
\text { Estate Fund }\end{array}$ & 12.77 & $\begin{array}{l}\text { Financial } \\
\text { services }\end{array}$ \\
\hline
\end{tabular}
underpricing indicators over period 2004-2020, \% 


\begin{tabular}{|c|c|c|c|}
\hline State & $\begin{array}{l}\text { Company } \\
\text { name }\end{array}$ & $\begin{array}{c}\text { Under- } \\
\text { pricing } \\
(\%)\end{array}$ & Industry \\
\hline & III & & \\
\hline Latvia & $\begin{array}{l}\text { SAF } \\
\text { Tehnika }\end{array}$ & 12.23 & $\begin{array}{l}\text { Telecommunic } \\
\text { a tions }\end{array}$ \\
\hline Latvia & HansaMatrix & 10.49 & Technology \\
\hline $\begin{array}{l}\text { Lithua } \\
\text { nia }\end{array}$ & Novaturas & 9.32 & $\begin{array}{l}\text { Travel and } \\
\text { recreation }\end{array}$ \\
\hline Estonia & Nordecon & 6.92 & $\begin{array}{l}\text { Construction } \\
\text { and materials }\end{array}$ \\
\hline $\begin{array}{l}\text { Lithuan } \\
\text { ia }\end{array}$ & $\begin{array}{l}\text { East West } \\
\text { Agro }\end{array}$ & 4.74 & $\begin{array}{l}\text { Industrial } \\
\text { goods and } \\
\text { services }\end{array}$ \\
\hline $\begin{array}{l}\text { Lithuan } \\
\text { ia }\end{array}$ & $\begin{array}{l}\text { Vilkyškių } \\
\text { pieninė }\end{array}$ & 2.14 & $\begin{array}{l}\text { Food, } \\
\text { beverages and } \\
\text { tobacco }\end{array}$ \\
\hline Estonia & $\begin{array}{l}\text { Tallink } \\
\text { Grupp }\end{array}$ & 0.70 & $\begin{array}{l}\text { Travel and } \\
\text { recreation }\end{array}$ \\
\hline $\begin{array}{l}\text { Lithuan } \\
\text { ia }\end{array}$ & $\begin{array}{l}\text { Linas Agro } \\
\text { Group }\end{array}$ & 0.35 & $\begin{array}{l}\text { Food, } \\
\text { beverages and } \\
\text { tobacco }\end{array}$ \\
\hline $\begin{array}{l}\text { Lithuan } \\
\text { ia }\end{array}$ & $\begin{array}{l}\text { AUGA } \\
\text { group }\end{array}$ & -0.43 & $\begin{array}{l}\text { Food, } \\
\text { beveragesand } \\
\text { tobacco }\end{array}$ \\
\hline $\begin{array}{l}\text { Lithuan } \\
\text { ia }\end{array}$ & Ignitis grupė & -1.08 & Improvement \\
\hline Estonia & Arco Vara & -2.95 & Real estate \\
\hline
\end{tabular}

Source: Author's table based on Nasdaq Baltic data

With the highest underpricing rate $-68.86 \%$ (see Table 1), Saunum Group stands out, a company listed on the First North alternative market from 2020. For institutional and private investors, its shares were sold for 2.84 euros, but the first day of trading ended with a price of 4.80 euros per share. The share price more than doubled due to the excessive demand. If the company's certified consultant, summarizing the demand and wishes of investors, raised the price, the company could get an additional hundreds of thousands of euros for the development of its business. The next company with one of the higher underpricing rates $-20.34 \%$, is the Estonian company Express Grupp. As in the case of Saunum Group, the demand for Express Grupp shares, both from institutional investors and individual investors six times exceeded the number of shares offered. For other companies with underpricing rates between $15 \%$ and $10 \%$, the shares were also significantly underestimated, as a result of which the company did not receive additional investments. However, the lowest underpricing of less than $10 \%$ is not so significant, since a slight price increase on the first day of trading is inevitable - there are investors who did not split the shares during the underwriting period, but who want to buy them; so are investors who want to earn by selling shares immediately. Less rapid price increases on the first day of quotation point to a fairer price, leading to more moderate demand. The negative level of underpricing for the last three companies in the table points to the opposite situation, when the shares of the company were overvalued and demand did not reach supply, resulting in a fall in the share price on the first day. It should be noted that the demand for shares can be influenced not only by the company itself and its indicators, but also by the global economic situation and the overall mood of investors in the market.

The average underpricing rate in the Baltic States is $11.08 \%$, similar to European countries such as Belgium (11\%), Poland (11.7\%) and Portugal (11.5\%). In turn, in Scandinavian countries the trends of underpricing are slightly different, for example, in Sweden it is as much as $25.9 \%$, in Finland $14.2 \%$, while in Denmark it is already two times lower $-7.4 \%$, while in Norway it is only $6.7 \%$ [8]. Despite the fact that the average level of underpricing in the Baltic States is not so high yet, the situation could change dramatically after several IPOs expected in the near future. Especially since a good mood of investors is currently being observed around the world and investors who are oriented towards investments in the Baltic States are very much looking forward to new and promising companies on the Nasdaq Baltic market.

\subsection{Assessment of Nasdaq Baltic's performance indicators by IPO}

Within the framework of the research, the IPO underperformance theory will be tested by comparing the financial performance of Nasdaq Baltic stock market companies three years before and three years after the IPO. The year of the company's IPO counts as the first year of the "postIPO". In total [22], four financial indicators will be compared: ROA (net profit/assets), ROE (net profit/equity), profit margin (net profit/net turnover), gross margin (gross profit/net turnover).

Of all companies listed on the Baltic Stock Exchange, only 17 companies were available for analysis. The data were taken from company issue prospectuses available on Nasdaq Baltic website and annual reports found in the official state registers. During the analysis, the sample of companies had to be reduced by two more companies, Aug Group and Arco Vara, as these companies entered the market during the financial crisis and suffered losses of several million euros starting in 2008. Such rapid changes in financial indicators had a huge impact on the overall results, so the decision was made to exclude both companies from the research. 
The first indicator that was verified is the profitability indicator for the ROA (see Table 2). Almost all but four companies have seen a fall in the indicator of ROA after an initial public offering. This is largely due to a sharp fall in net profit for all companies in the third year after the IPO, with the exception of just a few with a slight increase in profits.

Table 2. Nasdaq Baltic stock market company ROA indicator before and after IPO

\begin{tabular}{|l|r|r|r|r|}
\hline \multicolumn{1}{|c|}{ Name } & $\begin{array}{c}\text { Avera } \\
\text { ge } \\
\text { ROA }\end{array}$ & $\begin{array}{c}\text { Pre- } \\
\text { IPO } \\
\text { ROA }\end{array}$ & $\begin{array}{c}\text { Post } \\
\text { IPO } \\
\text { ROA }\end{array}$ & $\begin{array}{c}\text { Differen } \\
\text { ce ROA }\end{array}$ \\
\hline Linda Nektar & 18.3 & 26.0 & 10.5 & -15.6 \\
\hline Ekspress Grupp & 3.5 & 8.3 & -1.3 & -9.7 \\
\hline Vilkyškiu pienine & 8.0 & 12.6 & 3.3 & -9.3 \\
\hline Baltika & 5.9 & 9.4 & 2.4 & -7.1 \\
\hline East West Agro & 3.9 & 6.6 & 1.2 & -5.4 \\
\hline HansaMatrix & 5.4 & 6.5 & 4.4 & -2.1 \\
\hline Linas Agro Group & 7.4 & 7.8 & 6.9 & -0.9 \\
\hline $\begin{array}{l}\text { MADARACosme } \\
\text { tics }\end{array}$ & 14.9 & 15.3 & 14.4 & -0.9 \\
\hline Tallink Grupp & 7.9 & 8.1 & 7.7 & -0.5 \\
\hline Nordecon & 14.7 & 14.8 & 14.6 & -0.2 \\
\hline SAF Tehnika & 26.5 & 26.5 & 26.4 & 0.0 \\
\hline $\begin{array}{l}\text { Silvano Fashion } \\
\text { Group }\end{array}$ & 1.7 & 1.6 & 1.9 & 0.3 \\
\hline Harju Elekter & 14.2 & 13.9 & 14.5 & 0.6 \\
\hline Tallinna Vesi & 7.9 & 6.3 & 9.4 & 3.1 \\
\hline $\begin{array}{l}\text { Trigon Property } \\
\text { Development }\end{array}$ & 9.4 & 6.9 & 11.9 & 5.1 \\
\hline
\end{tabular}

Source: Author's table based on Nasdaq Baltic data

Before and after the IPO, the Wilcoxon test is used to compare ROA ratios. Consequently, the first hypothesis is as follows:

H0: ROA ratios of companies remains the same after an IPO;

$\mathrm{H} 1$ : ROA ratios of companies decreases after an IPO.

After the z-test performed (see Table 3), the H1 hypothesis is rejected because the p-value is 0,12 , which is more than 0,05 , as well as the $\mathrm{z}$-statistical value is less than the $\mathrm{z}$-critical value $(1.56<1.95)$. Consequently, despite the fact that the average ROA decreased after the IPO, its difference is not statistically significant.
Table 3. Wilcoxon test results for ROA/ROE ratio of companies

\begin{tabular}{|l|r|r|r|r|}
\hline $\begin{array}{c}\text { z-Test: Two } \\
\text { Sample for } \\
\text { Means }\end{array}$ & $\begin{array}{c}\text { Pre- } \\
\text { IPO } \\
(\text { ROA })\end{array}$ & $\begin{array}{c}\text { Post- } \\
\text { IPO } \\
(\text { ROA })\end{array}$ & $\begin{array}{c}\text { Pre-IPO } \\
(\text { ROE })\end{array}$ & $\begin{array}{c}\text { Post- } \\
\text { IPO } \\
(\text { ROE })\end{array}$ \\
\hline Mean & 11.39 & 8.54 & 26.56 & 15.29 \\
\hline $\begin{array}{l}\text { Known } \\
\text { Variance }\end{array}$ & 67.76 & 80.92 & 242.67 & 288.28 \\
\hline Observations & 45 & 45 & 45 & 45 \\
\hline $\begin{array}{l}\text { Hypothesized } \\
\text { Mean Diff. }\end{array}$ & 0 & & 0 & \\
\hline $\mathrm{Z}$ & 1,56 & & 3.28 & \\
\hline $\begin{array}{l}\mathrm{P}(\mathrm{Z}<=\mathrm{z}) \text { one- } \\
\text { tail }\end{array}$ & 0.06 & & 0.000520 & \\
\hline $\begin{array}{l}\mathrm{z} \text { Critical one- } \\
\text { tail }\end{array}$ & 1.64 & & 1.64 & \\
\hline $\begin{array}{l}\mathrm{P}(\mathrm{Z}<=\mathrm{z}) \text { two- } \\
\text { tail }\end{array}$ & 0.12 & & 0.001040 & \\
\hline $\begin{array}{l}\mathrm{z} \text { Critical two- } \\
\text { tail }\end{array}$ & 1.96 & & 1.96 & \\
\hline
\end{tabular}

On the other hand, the distribution of the average ROE factor (see table 4) between companies is not as significant as in the case of ROA.

Table 4. Nasdaq Baltic stock market company ROE ratio before and after IPO

\begin{tabular}{|l|r|r|r|r|}
\hline \multicolumn{1}{|c|}{ Name } & $\begin{array}{c}\text { Avera } \\
\text { ge } \\
\text { ROE }\end{array}$ & $\begin{array}{c}\text { Pre- } \\
\text { IPO } \\
\text { ROE }\end{array}$ & $\begin{array}{c}\text { Post } \\
\text { IPO } \\
\text { ROE }\end{array}$ & $\begin{array}{r}\text { Differen } \\
\text { ce ROE }\end{array}$ \\
\hline Linda Nektar & 19.4 & 28.0 & 10.8 & -17.2 \\
\hline Ekspress Grupp & 13.0 & 27.7 & -1.7 & -29.3 \\
\hline Vilkyškių pieninė & 22.5 & 41.9 & 3.2 & -38.7 \\
\hline Baltika & 12.3 & 20.0 & 4.7 & -15.3 \\
\hline East West Agro & 24.0 & 41.7 & 6.3 & -35.4 \\
\hline Hansa Matrix & 20.1 & 28.8 & 11.4 & -17.5 \\
\hline Linas Agro Group & 19.4 & 23.4 & 15.3 & -8.1 \\
\hline $\begin{array}{l}\text { MADARA } \\
\text { Cosmetics }\end{array}$ & 20.5 & 23.8 & 17.1 & -6.6 \\
\hline Tallink Grupp & 22.4 & 24.1 & 20.7 & -3.4 \\
\hline Nordecon & 46.8 & 54.1 & 39.4 & -14.7 \\
\hline SAF Tehnika & 29.3 & 26.7 & 31.9 & 5.2 \\
\hline $\begin{array}{l}\text { Silvano Fashion } \\
\text { Group }\end{array}$ & 4.6 & 5.5 & 3.7 & -1.8 \\
\hline Harju Elekter & 22.7 & 20.6 & 24.9 & 4.3 \\
\hline Tallinna Vesi & 17.7 & 15.3 & 20.1 & 4.8 \\
\hline $\begin{array}{l}\text { TrigonPropertyDev } \\
\text { elopment }\end{array}$ & 19.3 & 16.8 & 21.7 & 4.9 \\
\hline
\end{tabular}

Source: Author's table based on Nasdaq Baltic data

For several companies it is around $15 \%-20 \%$, which counts well enough, however, companies with particularly high or low ROE are also found. Before and after the IPO, the difference in the ratio is mostly negative again, which indicates that the financial performance of the companies decreased after an initial public offer. It is necessary to verify 
whether the change after the IPO is statistically significant.

In order to verify whether the reduction in the ROE coefficient after the IPO is statistically significant, the following hypotheses were set for the z-test:

H0: ROE ratios of companies remains the same after an IPO;

$\mathrm{H} 1$ : ROE ratios of companies decreases after an IPO.

Based on the calculated result (see Table 3), it can be seen that the p-value is below $0,05(0,001)$ and the $\mathrm{z}$-statistical value is greater than the $\mathrm{z}$ critical, thus the $\mathrm{H} 1$ hypothesis is confirmed and the reduction of the ROE coefficient for the Companies of the Baltic stock market is statistically significant. The average ROE before the IPO is $26.56 \%$, while after the IPO only $15.29 \%$, thus showing significant drop.

The next indicator considered is the profit margin or the profitability of turnover. The NMP ratio indicates the percentage of the company's net profit on net turnover (see Table 5).

Table 5. Nasdaq Baltic stock market company profit margin before and after IPO

\begin{tabular}{|l|r|r|r|r|}
\hline \multicolumn{1}{|c|}{ Name } & $\begin{array}{c}\text { Avera } \\
\text { ge } \\
\text { NMP }\end{array}$ & $\begin{array}{c}\text { Pre- } \\
\text { IPO } \\
\text { NMP }\end{array}$ & $\begin{array}{c}\text { Post } \\
\text { IPO } \\
\text { NMP }\end{array}$ & $\begin{array}{c}\text { Differen } \\
\text { ce NMP }\end{array}$ \\
\hline Linda Nektar & 16.4 & 18.9 & 13.9 & -4.9 \\
\hline Ekspress Grupp & 2.0 & 6.3 & -2.3 & -8.7 \\
\hline Vilkyškių pieninè & 3.4 & 5.9 & 0.9 & -5.0 \\
\hline Baltika & 5.2 & 8.5 & 1.8 & -6.7 \\
\hline East West Agro & 2.7 & 4.5 & 0.9 & -3.6 \\
\hline HansaMatrix & 5.7 & 7.0 & 4.4 & -2.7 \\
\hline Linas Agro Group & 3.8 & 3.4 & 4.1 & 0.7 \\
\hline $\begin{array}{l}\text { MADARACosme } \\
\text { tics }\end{array}$ & 14.5 & 12.7 & 16.2 & 3.6 \\
\hline Tallink Grupp & 12.5 & 10.3 & 14.7 & 4.4 \\
\hline Nordecon & 5.5 & 4.4 & 6.6 & 2.2 \\
\hline SAF Tehnika & 13.5 & 8.1 & 18.9 & 10.8 \\
\hline $\begin{array}{l}\text { Silvano Fashion } \\
\text { Group }\end{array}$ & 2.1 & 1.1 & 3.1 & 2.0 \\
\hline Harju Elekter & 12.6 & 12.9 & 12.3 & -0.6 \\
\hline Tallinna Vesi & 33.7 & 28.5 & 38.9 & 10.4 \\
\hline $\begin{array}{l}\text { TrigonPropertyDe } \\
\text { velopment }\end{array}$ & 7.1 & 4.8 & 9.3 & 4.5 \\
\hline
\end{tabular}

Source: Author's table based on Nasdaq Baltic data

The NMP ratio varies considerably across all companies. For many companies, the ratio is less than 5\%, which, however, is considered low. The difference between pre- and post-IPO indicators is negative for a smaller number of companies. Mainly all companies with a positive difference did not experience such a sharp drop in income after the implemented initial offer. While a decrease in ROA and ROE factors after the IPO was observed, there is still a slight increase in the case of MPRs, so the z-test hypotheses are as follows:

H0: The NMP ratios of companies remains the same after an IPO;

H1: The NMP ratios of companies decreases after an IPO.

Undoubtedly, too small an increase in the average NMP ratio after the IPO from $9.15 \%$ to $9.58 \%$ was not considered statistically significant (see Table 6), as the $\mathrm{H} 1$ hypothesis was rejected due to too large p-value $(0.834>0.05)$.

Table 6. Wilcoxone test results for the NMP score of companies

\begin{tabular}{|l|r|r|r|r|}
\hline $\begin{array}{c}\text { z-Test: Two } \\
\text { Sample for } \\
\text { Means }\end{array}$ & $\begin{array}{c}\text { Pre- } \\
\text { IPO } \\
\text { NMP }\end{array}$ & $\begin{array}{c}\text { Post- } \\
\text { IPO } \\
\text { NMP }\end{array}$ & $\begin{array}{c}\text { Pre- } \\
\text { IPO } \\
\text { OMP }\end{array}$ & $\begin{array}{c}\text { Post- } \\
\text { IPO } \\
\text { OMP }\end{array}$ \\
\hline Mean & 9.15 & 9.58 & 31.36 & 31.33 \\
\hline $\begin{array}{l}\text { Known } \\
\text { Variance }\end{array}$ & 56.31 & 131.65 & 335.62 & 375.71 \\
\hline Observations & 45 & 45 & 45 & 45 \\
\hline $\begin{array}{l}\text { Hypothesized } \\
\text { Mean Diff. }\end{array}$ & 0 & & 0 & \\
\hline $\mathrm{z}$ one- & 0.42 & & 0.49 & \\
\hline $\begin{array}{l}\mathrm{P}(\mathrm{Z}<=\mathrm{z}) \\
\text { tail }\end{array}$ & 1.64 & & 1.64 & \\
\hline $\begin{array}{l}\mathrm{z} \text { Critical one- } \\
\text { tail }\end{array}$ & 0.834 & & 0.9942 & \\
\hline $\begin{array}{l}\mathrm{P}(\mathrm{Z}<=\mathrm{z}) \text { two- } \\
\text { tail }\end{array}$ & 0.960 & & 1.9599 & \\
\hline $\begin{array}{l}\mathrm{z} \text { Critical two- } \\
\text { tail }\end{array}$ & 1.96073 & \\
\hline
\end{tabular}

The last factor analyzed in this research is the gross profit margin ratio (see Table 7). OMP indicates how much the company earns for each euro of turnover, covering operating expenses.

Table 7. Nasdaq Baltic stock market corporate gross margin ratio before and after IPO

\begin{tabular}{|l|r|r|r|r|}
\hline \multicolumn{1}{|c|}{ Name } & $\begin{array}{c}\text { Avera } \\
\text { ge } \\
\text { OMP }\end{array}$ & $\begin{array}{c}\text { Pre- } \\
\text { IPO } \\
\text { OMP }\end{array}$ & $\begin{array}{l}\text { Post } \\
\text { IPO } \\
\text { OMP }\end{array}$ & $\begin{array}{l}\text { Differen } \\
\text { ce OMP }\end{array}$ \\
\hline Linda Nektar & 46.4 & 46.7 & 46.2 & \multicolumn{1}{l|}{-0.5} \\
\hline Ekspress Grupp & 24.0 & \multicolumn{1}{|c|}{25.7} & 22.3 & \multicolumn{1}{|c|}{-3.3} \\
\hline Vilkyškių pieninė & 11.4 & 14.0 & 8.7 & -5.3 \\
\hline Baltika & 53.7 & 52.7 & 54.7 & 2.0 \\
\hline East West Agro & 16.7 & 15.6 & 17.8 & 2.2 \\
\hline Hansa Matrix & 20.8 & 24.1 & 17.4 & -6.6 \\
\hline Linas Agro Group & 7.2 & 7.2 & 7.1 & -0.1 \\
\hline MADARA & 59.6 & 56.6 & 62.6 & 6.0 \\
\hline
\end{tabular}




\begin{tabular}{|l|r|r|r|r|}
\hline \multicolumn{1}{|c|}{ Name } & $\begin{array}{c}\text { Avera } \\
\text { ge } \\
\text { OMP }\end{array}$ & $\begin{array}{c}\text { Pre- } \\
\text { IPO } \\
\text { OMP }\end{array}$ & $\begin{array}{c}\text { Post } \\
\text { IPO } \\
\text { OMP }\end{array}$ & $\begin{array}{r}\text { Differen } \\
\text { ce OMP }\end{array}$ \\
\hline Cosmetics & & & & \\
\hline Tallink Grupp & 26.7 & 26.0 & 27.3 & 1.3 \\
\hline Nordecon & 10.8 & 10.1 & 11.6 & 1.5 \\
\hline SAF Tehnika & 36.6 & 34.6 & 38.7 & 4.1 \\
\hline $\begin{array}{l}\text { Silvano Fashion } \\
\text { Group }\end{array}$ & 62.0 & 66.6 & 57.4 & -9.2 \\
\hline Harju Elekter & 19.0 & 19.6 & 18.3 & -1.3 \\
\hline Tallinna Vesi & 52.8 & 49.6 & 56.0 & 6.4 \\
\hline $\begin{array}{l}\text { Trigon Property } \\
\text { Development }\end{array}$ & 22.6 & 21.4 & 23.8 & 2.4 \\
\hline
\end{tabular}

Source: Author's table based on Nasdaq Baltic data

The average gross margin ratio is mostly high, however, there are some low-performing companies, such as the Lithuanian dairy company Vilkyškiu pieninè. Despite the fact that the company's turnover increased after the IPO, the prices of dairy products fell sharply due to the fact that there was too much milk product supply in Europe. As a result, the company's gross profit ratio is significantly lower than that of other companies. On the other hand, the average OMP difference before and after the IPO does not look significant $31.36>31.33$, so the hypotheses for the z-test test are as follows:

H0: Following the initial public offering, the indicators of OMP remain unchanged;

H1: Following the initial public offering, the indicators of OMP decreases.

The statistical results in Table 6 show that the calculated p-value is greater than $0.05(0.99)$ and the z-critical is higher than the z-statistical (1,95>0,0073), thus rejecting the H1 hypothesis and the average difference between OMP results before and after the IPO is not statistically significant.

Thus, of the four compared financial indicators for Baltic stock market companies before and after the initial public offer, only the ROE ratio decreased statistically significantly after the IPO, indicating that investors' return on investment in company shares decreases within three years of the IPO. Studies between countries show different results, however, the results of this analysis coincide with theoretical claims of a deterioration in the performance of companies after IPOs and works, where a drop in the performance of enterprises after the listing on the Stock Exchange is observed. The reason for the decrease in indicators is considered to be the over-performance of the companies just before the IPO and overly optimistic forecasts of management for further development for attracting investors, which does not come true [20].

\section{Conclusion}

The average underpricing in the Baltic states is $11.08 \%$, which is similar for European countries such as Belgium (11\%), Poland (11.7\%) and Portugal $(11.5 \%)$. Of the four financial indicators compared (ROA, ROE, NMP, OMP), only the ROE ratio decreased statistically significantly after the IPO for Baltic stock market companies before and after the initial public offering, indicating that investors' return on investment in company shares is decreasing within three years of the IPO. The results of the analysis are consistent with theoretical claims about the deterioration of the company performance after the IPOs and works, that observe a decline in company performance after the IPOs listing on the Stock Exchange.

\section{References:}

[1] Praude V., Financial instruments, Riga: SIA Burtene, 2009

[2] PWC, Considering an IPO? First, understand the costs,

https://www.pwc.com/us/en/services/deals/libr a ry/cost-of-an-ipo.html

[3] Chemmanur T.J., Krishnan K., Heterogeneous Beliefs, IPO Valuation, and the Economic Role of the Underwriter in IPOs, Financial Management, Vol. 41, No. 4, 2012, p. 807-808

[4] Roosenbooma P. Valuing and pricing IPOs, Journal of Banking \& Finance, Volume 36, Issue 6, 2012, p. 1654-1655

[5] Deloof M., De Maeseneire W., Inghelbrecht K., How Do Investment Banks Value Initial Public Offerings (IPOs)?, Journal of Business Finance \& Accounting, 36(1) \& (2), 2012, p. 142

[6] Marupov D. M., Valuation of the organization's business at the stage of entering the equity capital market, Fundamental Research, No. 11-2, 2013, pp. 277-281.

[7] Ritter J.R., Money Left on the Table in IPOs by Firm, University of Florida, 2021

[8] Loughran T., Ritter J.R., Rydqvist K., Initial Public Offerings: International Insights, Pacific- Basin Finance Journal, Vol. 2, 2021, p. $165-199$

[9] Lukashov A., Mogin A., IPO from I to $O$, Handbook for CFOs and Investment Analysts, Alpina Publisher, 2008, 2nd edition 
[10] Coakley J., Instefjord N., Shen Z., The Winner's Curse and Lottery-Allocated IPOs in China, University of Essex, 2007, p. 18-19

[11] LaCroix K.M., Does Increased IPO Activity Foreshadow Increased IPO-Related Securities Litigation Ahead?, https://www.dandodiary.com/2020/11/articles/i $\mathrm{p}$ os/does-increased-ipo-activity-foreshadowincreased-ipo-related-securities-litigationahead/

[12] Gilmartin Group, Director \& Officer $(D \& O)$ insurance for an IPO, https://gilmartinir.com/director-officer-doinsurance-for-an-ipo/

[13] Ritter J.R., Equilibrium in the Initial Public Offering Market, Annual Review of Financial Economics, Vol. 3, 2011, p. 28

[14] Rydqvist K., IPO underpricing as tax-efficient compensation, Journal of Banking \& Finance 21, 1997, p. 296

[15] Kokorev D.A., Chistyakov A.G., Initial public offerings of shares: the main anomalies under study, Journal of Corporate Finance, No. 4 (24), 2012, pp. 148-149

[16] Ritter J.R., Initial Public Offerings: Updated Statistics on Long-run Returns 2021, https://site.warrington.ufl.edu/ritter/files/IPOstatistics-longrun.pdf

[17] Bruzgyte E., Guliyeva G., IPO Underpricing in NASDAQ First North Stockholm: Can Investors Beat the Market?, Lund University, 2016, p. 29

[18] Brau J.C., Couch R.B., Sutton N.K., The Desire to Acquire and IPO Long-Run Underperformance, The Journal of Financial and Quantitative Analysis, Vol.47, N.3, 2012, p.493-510

[19] Solovjova, I. New Approaches to Regulating the Activities of Rating Agencies: a Comparative Analysis. // Procedia - Social and Behavioral Sciences, 2016, Vol. 229: 5th International Conference on Leadership, Technology, Innovation and Business Management, p.115-125

[20] Ahmad Z., Suh Mei L., Operating Performance of Initial Public Offerings in Malaysia, Capital Markets Review, Vol.13 No.1\&2 (Special Issue), 2005, p. 27-28

[21] Fullbrunn, S., Neugebauer, T. \& Nicklisch, A. Underpricing of initial public offerings in experimental asset markets. Experimental Economics, Vol.23, 2020, p.1002-1029

[22] Solovjova I., Romanova I. Bank Reliability Assessment Model: Case of Latvia, Eurasian Business Perspectives: Proceedings of the 25th
Eurasia Business and Economics Society Conference, Eurasian Studies in Business and Economics, Vol. 12/2, Cham:Springer Nature, 2021 p. 285-298.

\section{Sources of Funding for Research Presented in a Scientific Article or Scientific Article Itself}

This work has been supported by the European Social Fund within the Project No 8.2.2.0/20/I/008 «Strengthening of $\mathrm{PhD}$ students and academic personnel of Riga Technical University and BA School of Business and Finance in the strategic fields of specialization» of the Specific Objective 8.2.2 «To Strengthen Academic Staff of Higher Education Institutions in Strategic Specialization Areas» of the Operational Programme «Growth and Employment»

\section{Creative Commons Attribution License 4.0 (Attribution 4.0 International, CC BY 4.0)} This article is published under the terms of the Creative Commons Attribution License 4.0 https://creativecommons.org/licenses/by/4.0/deed.en US 